Portland State University

PDXScholar

\title{
Modeling of DC Link Capacitor Current Ripple for Electric Vehicle Traction Converter
}

Lei Jin

Oregon State University

Julia Zhang

Oregon State University

Follow this and additional works at: https://pdxscholar.library.pdx.edu/trec_reports

Part of the Transportation Commons, Urban Studies Commons, and the Urban Studies and Planning Commons

Let us know how access to this document benefits you.

\section{Recommended Citation}

Julia Zhang and Lei Jin. Modeling of DC link Capacitor Current Ripple for Electric Vehicle Traction Converter. OTREC-SS-634. Portland, OR: Transportation Research and Education Center (TREC), 2010. https://doi.org/10.15760/trec.40

This Report is brought to you for free and open access. It has been accepted for inclusion in TREC Final Reports by an authorized administrator of PDXScholar. Please contact us if we can make this document more accessible: pdxscholar@pdx.edu. 


\section{G) OTREC}

FINAL REPORT

Modeling of DC Link
Capacitor Current Ripple For Electric

Vehicle Traction

Converter

OTREC-SS-634

September 2013 



\title{
MODELING OF DC LINK CAPACITOR CURRENT RIPPLE FOR ELECTRIC VEHICLE TRACTION CONVERTER \\ Draft Report
}

\section{OTREC-SS-634}

\author{
by \\ Lei Jin \\ Advisor: Julia Zhang \\ Oregon State University \\ for \\ Oregon Transportation Research \\ and Education Consortium (OTREC) \\ P.O. Box 751 \\ Portland, OR 97207

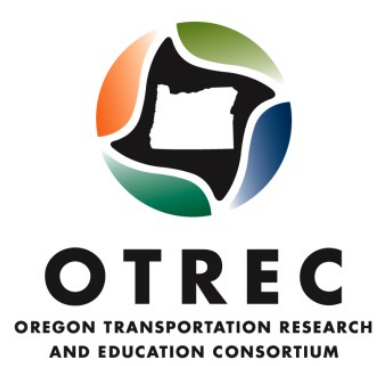

September 2013 



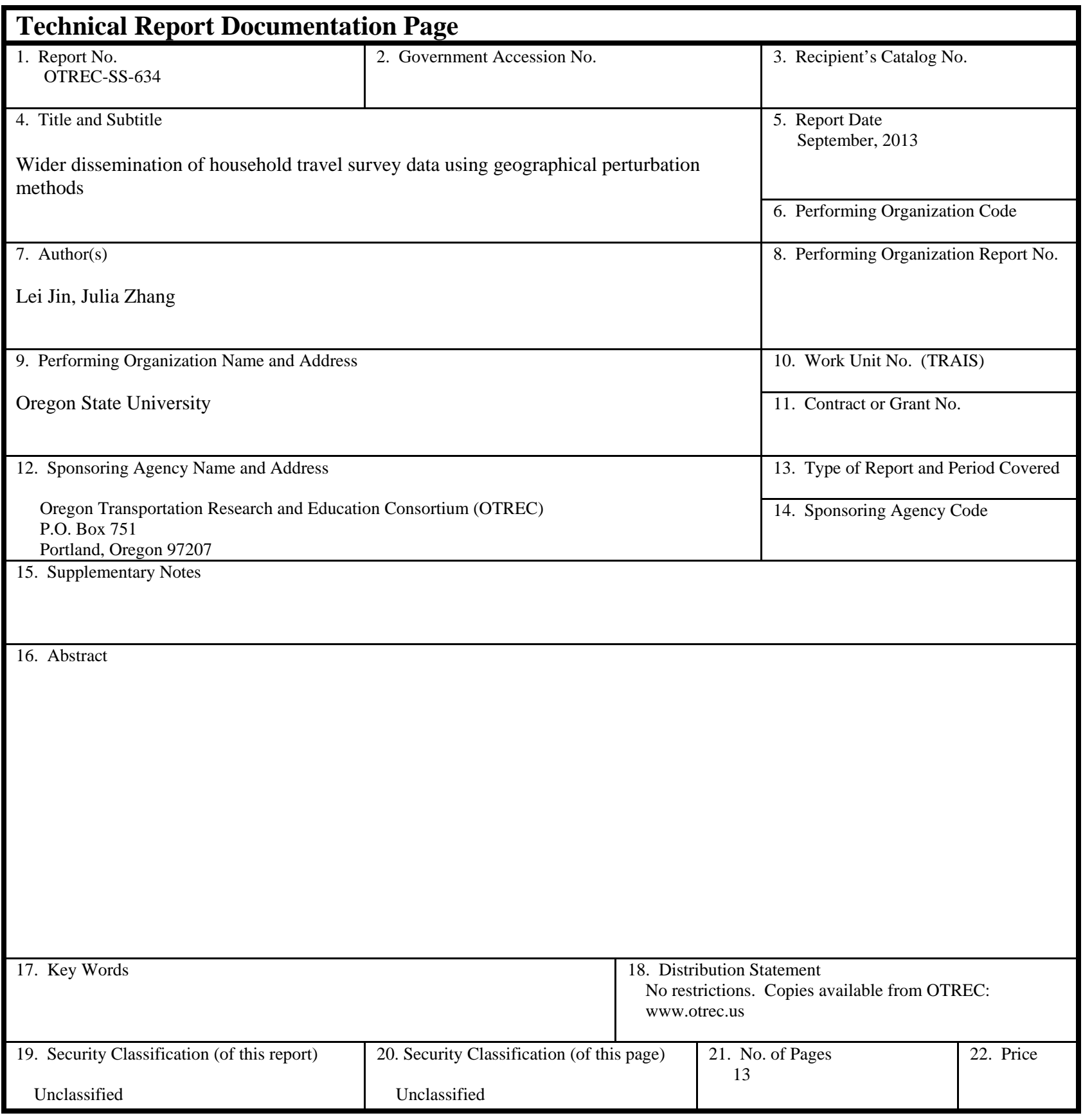





\title{
Modeling of DC Link Capacitor Current Ripple for Electric Vehicle Traction Converter
}

\author{
Lei Jin \\ Advisor: Julia Zhang \\ School of Electrical Engineering and Computer Science \\ Oregon State University \\ $09 / 28 / 2013$
}





\section{Table of Contents}

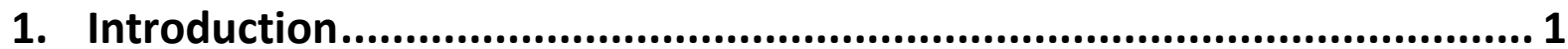

2. Space Vector PWM Fundamentals ....................................................... 1

3. Average Value of Inverter Input Current ............................................ 2

4. RMS Value of Inverter Input Current .................................................. 3

5. RMS Value of DC Link Capacitor Current Ripple..................................... 4

6. Numerical Method of Calculating Instantaneous Capacitor Current Ripple 5

7. Analysis for Non-ideal Voltage Source.............................................. 10

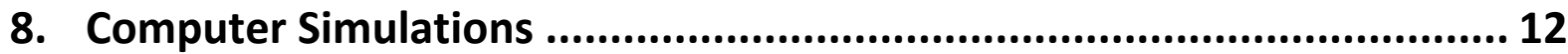

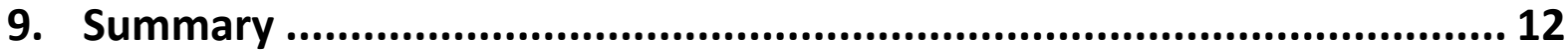

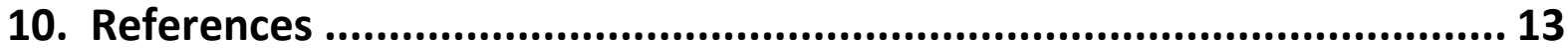





\section{Introduction}

Contemporary Full Hybrid Electric Vehicle/Plug-in Hybrid Electric Vehicle/Battery Electric Vehicle (FHEV/PHEV/BEV) products use one or more DC/AC power converters, also known as traction inverters, to convert the DC voltage/current provided by the traction battery to the $A C$ voltage/current to drive the traction motor(s). Large and bulky DC link capacitors are used at the input of the traction inverter to provide a smooth DC input voltage. Those DC link capacitors, occupying almost $50 \%$ of the space in the whole package, can contribute to more than $20 \%$ of the total cost of the traction inverter. They are generally over-designed to assure a large safety margin during the fast transient operation of the electric machine(s). However, it is not well understood how the capacitor size reduction affects the electric machine drive system performance and operation stability. This work presents the numerical method of calculating the DC link capacitor current ripple of the traction converter for electric vehicle applications. The effect of internal resistance of the input voltage source is taken into account for the math modeling. This provides guidance to the minimum boundary of the DC link capacitor size of traction power inverters for the application of battery electric vehicles.

Figure 1 shows a typical topology of the electric machine drive system for an FHEV/PHEV. The DC/DC converter, boosting the traction battery voltage to a higher DC voltage, may not exist for a BEV. The two traction inverters convert the $D C$ voltage to $A C$ voltage to drive electric machines. A BEV may only have one traction inverter and one electric machine.

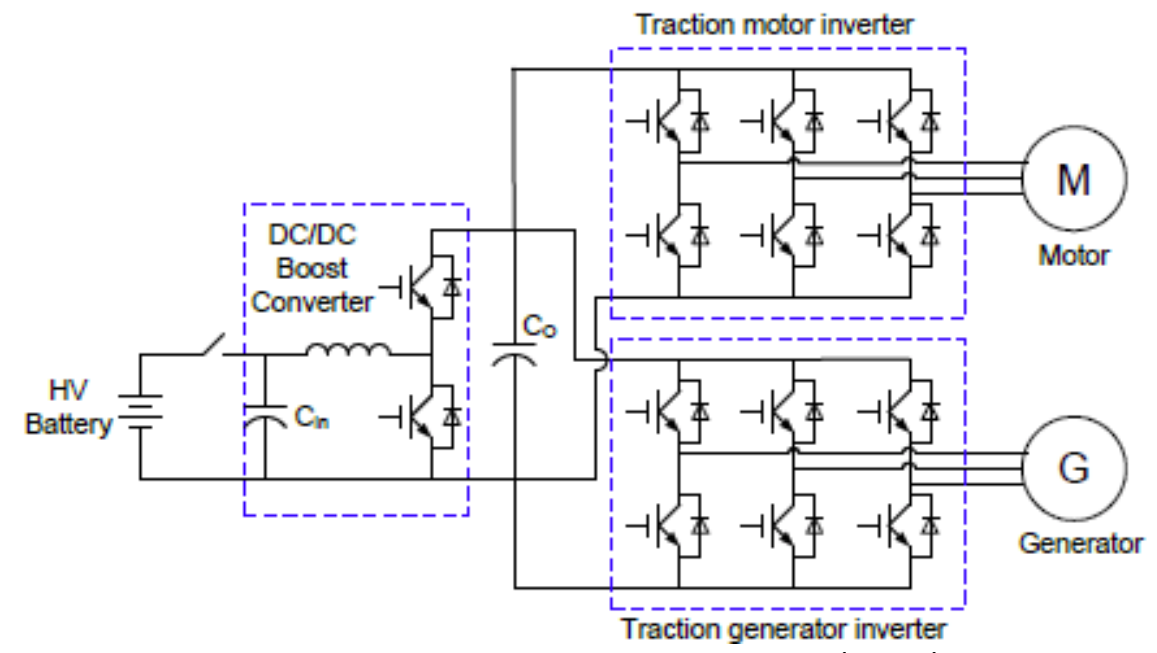

Figure 1 Electric machine drive topology on FHEV/PHEV/BEV

\section{Space Vector PWM Fundamentals}

We introduce the space vector pulse width modulation (SVPWM) fundamentals first. Secondly, we discuss the numerical method of calculating the root mean square (RMS) value of the capacitor current ripple. Figure 2 shows a three-phase voltage source inverter (VSI). The load of the inverter is a back electromotive force (EMF) source in series with an inductor to represent a three-phase electric machine. For each of the three phases, Status " 1 " means that the top switch turns on and vice versa. In Status " 0 " the bottom switch turns on. Figure 3 shows all eight voltage vectors that a three-phase VSI may have. They are (100), (110), (010), (011), (001), (101), (111) 
and (000). Among the eight voltage vectors, six are the active voltage vectors and two are the zero--voltage vectors $(000,111)$.

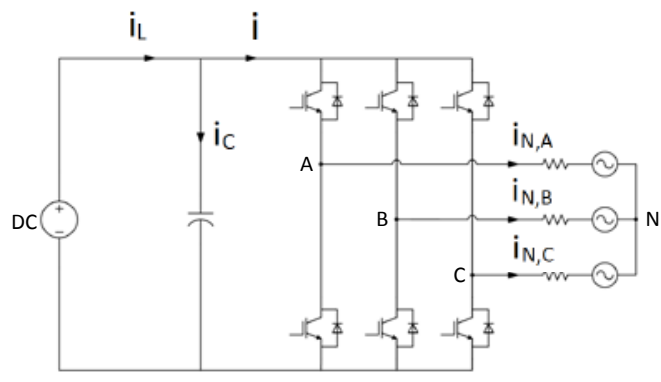

Figure 2 Three-phase voltage source inverter

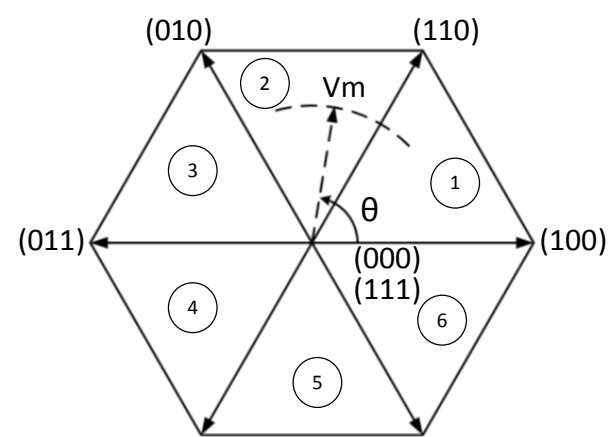

(001)

(100)

Figure 3 Six active voltage vectors and two zero--voltage vectors

A rotating voltage vector command may be expressed as:

$$
\begin{aligned}
& \overrightarrow{V_{m}}=V_{m} \exp (j \theta) \\
& \theta=\omega t
\end{aligned}
$$

where $V_{m}$ is the magnitude of the command voltage vector, $\theta$ the angle of the voltage vector, and $\omega$ the electrical angular velocity of the voltage vector. Various definitions exist for the modulation index. In our study, we define the modulation index as:

$$
M=\frac{V_{m}}{0.5 V_{d c}}
$$

where $V_{d c}$ is the DC bus voltage. For this definition, the maximum value of the modulation index is $2 / \sqrt{3}$ when the six-step control is applied to the load.

In Figure 3, the rotating command voltage vector lies in the second sector. In this case, this command voltage vector will be generated by the four voltage vectors in the second sector: 110, 010,000 and 111 . For the SVPWM algorithm, the duty cycle of each voltage vector may be written as:

$$
\begin{aligned}
& D_{(010)}=\frac{t_{(010)}}{T_{s}}=\frac{\sqrt{3} M}{2} \sin \left(\theta-\frac{\pi}{3}\right) \\
& D_{(110)}=\frac{t_{(110)}}{T_{s}}=\frac{\sqrt{3} M}{2} \sin \left(\theta+\frac{\pi}{3}\right) \\
& D_{(000)}=D_{(111)}=0.5\left(1-D_{(010)}-D_{(110)}\right)
\end{aligned}
$$

where $T_{s}$ is one switching cycle, $t_{(010)}$ and $t_{(110)}$ are the time durations when vectors 010 and 110 are applied, respectively.

\section{Average Value of Inverter Input Current}

For the " $Y$ " connection load shown in Figure 1, the sum of the three phase currents is zero:

$$
i_{N, A}+i_{N, B}+i_{N, C} \equiv 0
$$

In the time domain, the three phase currents can be expressed as:

$$
\begin{aligned}
& \mathrm{i}_{\mathrm{N}, \mathrm{A}}=I_{m} \cos (\theta-\varphi) \\
& i_{N, B}=I_{m} \cos \left(\theta-\frac{2 \pi}{3}-\varphi\right)
\end{aligned}
$$


$i_{N, C}=I_{m} \cos \left(\theta+\frac{2 \pi}{3}-\varphi\right)$

where $I_{m}$ is the magnitude of phase current, $\phi$ denotes the angle that the current is lagging the voltage. The space vector form of the three-phase current is written as:

$\overrightarrow{I_{m}}=I_{m} \exp \{j(\theta-\varphi)\}$

Figure 4 shows the inverter input current and the three-phase switching signals in two switching cycles.

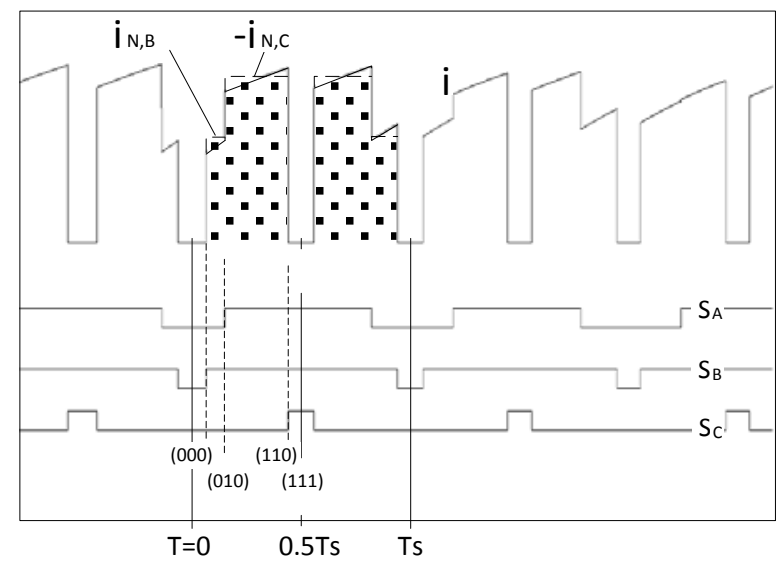

Figure 4. Inverter input current and three-phase switching signals

Assuming that the instantaneous value of the inverter input current is $i$, the average value of the inverter input current in one switching cycle, $i_{\text {avg }}$, can be expressed as:

$$
\begin{aligned}
i_{\text {avg }} & =\frac{2}{T_{s}} \int_{0}^{\frac{1}{2} T_{s}} i(t) d t \\
i_{\text {avg }} & =D_{(010)} i_{N, B}-D_{(110)} i_{N, C}
\end{aligned}
$$

Substituting Eqs. (3) to (6) and Eqs. (8) to (10) into Eq. (13), the average inverter input current may be rewritten as:

$$
i_{\text {avg }}=\frac{\sqrt{3} M}{2} \sin \left(\theta-\frac{\pi}{3}\right) \cdot I_{m} \cos \left(\theta-\frac{2 \pi}{3}-\varphi\right)-\frac{\sqrt{3} M}{2} \sin \left(\theta+\frac{\pi}{3}\right) \cdot I_{m} \cos \left(\theta+\frac{2 \pi}{3}-\varphi\right)
$$

The above equation may be further simplified as:

$$
i_{\text {avg }}=I_{\text {avg }}=\frac{3}{4} I_{m} M \cos \varphi
$$

It can be seen that the average value of the inverter input current is a function of the phase current magnitude, modulation index and the angle between the current and voltage vectors - in other words, the power factor.

\section{RMS Value of Inverter Input Current}

The RMS value of the inverter input current in one switching cycle $T_{S}$ can be expressed as:

$$
i_{r m s}^{2}=\frac{2}{T_{s}} \int_{0}^{\frac{1}{2} T_{s}} i^{2} d t
$$


Substituting Eqs. (3) to (6) and Eqs. (8) to (10) into Eq. (16), the RMS inverter input current may be rewritten as,

$$
i_{r m s}^{2}=D_{(010)} i_{N, B}^{2}+D_{(110)} i_{N, C}^{2}
$$

The lowest harmonic in the inverter input current is six times the fundamental frequency of the phase current, as shown in Figure 5.

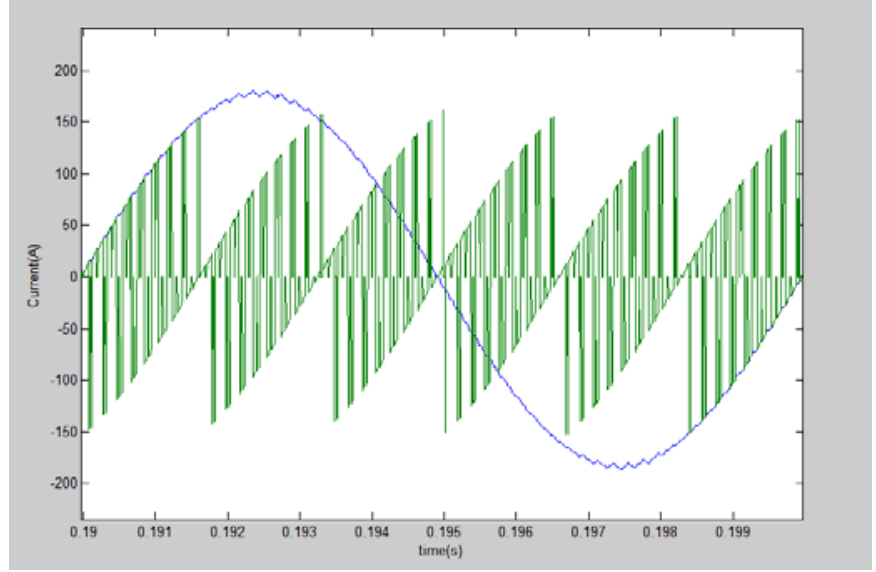

Figure 5. Inverter input current for pure resistive load

The RMS value of the inverter input current can be written as:

$$
I_{r m s}^{2}=\frac{3}{\pi} \int_{\frac{\pi}{3}}^{\frac{2 \pi}{3}} i_{r m s}^{2} d \theta
$$

Substituting Eqs. (3) to (6) and Eqs. (8) to (10) into Eq. (18), the RMS value of the inverter input current $I_{r m s}$ can be written as:

$$
\begin{aligned}
& I_{r m s}^{2}=\frac{3}{\pi} \int_{\frac{\pi}{3}}^{\frac{2 \pi}{3}}\left(D_{(010)} i_{N, B}^{2}+D_{(110)} i_{N, C}^{2}\right) d \theta \\
& I_{r m s}^{2}=\frac{3}{\pi} \int_{\frac{\pi}{3}}^{\frac{2 \pi}{3}}\left\{\frac{\sqrt{3} M}{2} \sin \left(\theta-\frac{\pi}{3}\right)\left[I_{m} \cos \left(\theta-\frac{2 \pi}{3}-\varphi\right)\right]^{2}+\frac{\sqrt{3} M}{2} \sin \left(\theta+\frac{\pi}{3}\right)\left[I_{m} \cos \left(\theta+\frac{2 \pi}{3}-\varphi\right)\right]^{2}\right\} d \theta \\
& I_{r m s}=\frac{I_{m}}{\sqrt{2}} \sqrt{\frac{2 \sqrt{3}}{\pi} M\left(\frac{1}{4}+\cos ^{2} \varphi\right)}
\end{aligned}
$$

where $I_{\mathrm{m}}$ is the peak value of the phase current, $M$ the modulation index, $\varphi$ the angle between the current vector and the voltage vector.

\section{RMS Value of DC Link Capacitor Current Ripple}

The input inverter current, $i$, is composed of the AC and DC component:

$$
i=i_{a c}+i_{d c}=i_{a c}+i_{a v g}
$$

The DC component is equal to the average value obtained in Eq. (15). The RMS value of the inverter input current can be expressed as:

$$
I_{r m s}^{2}=I_{a c, r m s}^{2}+I_{d c}^{2}=I_{a c, r m s}^{2}+I_{a v g}^{2}
$$

Let us assume the AC component is absorbed by the DC link capacitor completely.

$$
I_{a c, r m s}^{2}=I_{C, r m s}^{2}
$$

The RMS value of the capacitor current may be written as:

$$
I_{C, r m s}^{2}=I_{r m s}^{2}-I_{\text {avg }}^{2}
$$


Substituting Eqs. (15) and (21) into Eq. (23), the RMS value of capacitor current ripple can be written as:

$$
\begin{aligned}
& I_{C, r m s}=\sqrt{I_{N, r m s}^{2} \frac{2 \sqrt{3}}{\pi} M\left(\frac{1}{4}+\cos ^{2} \varphi\right)-\left(\frac{3}{4} I_{m} M \cos \varphi\right)^{2}} \\
& I_{C, r m s}=I_{N, r m s} \sqrt{2 M\left[\frac{\sqrt{3}}{4 \pi}+\cos ^{2} \varphi\left(\frac{\sqrt{3}}{\pi}-\frac{9}{16} M\right)\right]}
\end{aligned}
$$

Figure 6 shows the capacitor current ripple constant versus various power factor and modulation index. It can be seen that the maximum modulation index does not necessarily yield the highest capacitor current ripple.

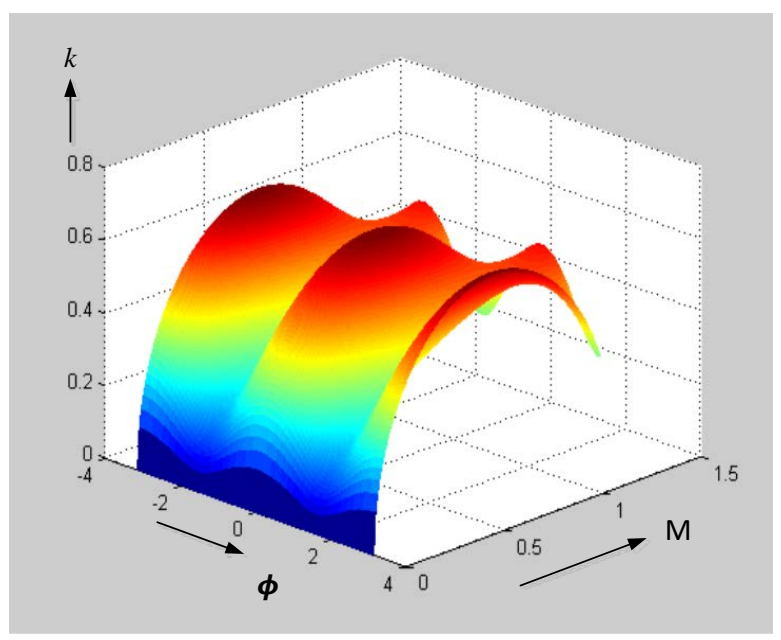

Figure 6. Capacitor current ripple constant vs. power factor and modulation index

\section{Numerical Method of Calculating Instantaneous Capacitor Current Ripple}

First, we calculate the instantaneous three-phase current using a pure inductance load. Figure 7 shows six switching patterns. The "green" power switches are the switches which are conducting current.
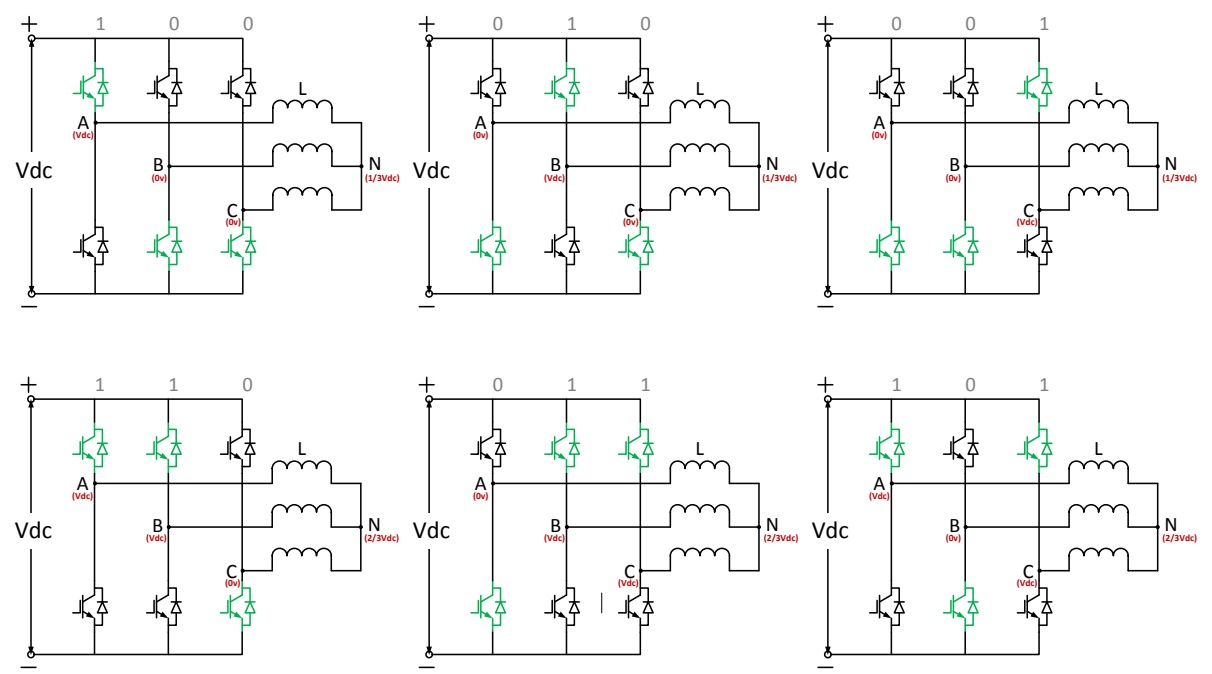

Figure 7. Six switching patterns (L load) 
The current change in one switching cycle is given by Eqs. (26) to (31) to the above six switching patterns. When either one of the two zero-voltage vectors (000 and 111) is applied, the threephase current maintains unchanged in one switching cycle.
$\left\{\begin{array}{c}\Delta i_{A}=\frac{2 V_{d c}}{3 L} \Delta t \\ \Delta i_{B}=-\frac{V_{d c}}{3 L} \Delta t \\ \Delta i_{C}=-\frac{V_{d c}}{3 L} \Delta t\end{array}\right.$
$\left\{\begin{array}{c}\Delta i_{A}=-\frac{V_{d c}}{3 L} \Delta t \\ \Delta i_{B}=\frac{2 V_{d c}}{3 L} \Delta t \\ \Delta i_{C}=-\frac{V_{d c}}{3 L} \Delta t\end{array}\right.$
(27) $\left\{\begin{array}{l}\Delta i_{A}=-\frac{V_{d c}}{3 L} \Delta t \\ \Delta i_{B}=-\frac{V_{d c}}{3 L} \Delta t \\ \Delta i_{C}=\frac{2 V_{d c}}{3 L} \Delta t\end{array}\right.$
$\left\{\begin{array}{c}\Delta i_{A}=\frac{V_{d c}}{3 L} \Delta t \\ \Delta i_{B}=\frac{V_{d c}}{3 L} \Delta t \\ \Delta i_{C}=-\frac{2 V_{d c}}{3 L} \Delta t\end{array}\right.$
(26)
$\left\{\begin{array}{c}\Delta i_{A}=-\frac{2 V_{d c}}{3 L} \Delta t \\ \Delta i_{B}=\frac{V_{d c}}{3 L} \Delta t \\ \Delta i_{C}=\frac{V_{d c}}{3 L} \Delta t\end{array}\right.$
$\left\{\begin{array}{c}\Delta i_{A}=\frac{V_{d c}}{3 L} \Delta t \\ \Delta i_{B}=-\frac{2 V_{d c}}{3 L} \Delta t \\ \Delta i_{C}=\frac{V_{d c}}{3 L} \Delta t\end{array}\right.$
(30)

where $L$ is the inductance of the load.

Figure 8 shows six switching patterns with an electric machine load. The electric machine load is represented by an RL load in series with a back EMF voltage source. The current change in one switching cycle is given by Eqs. (32) to (37).

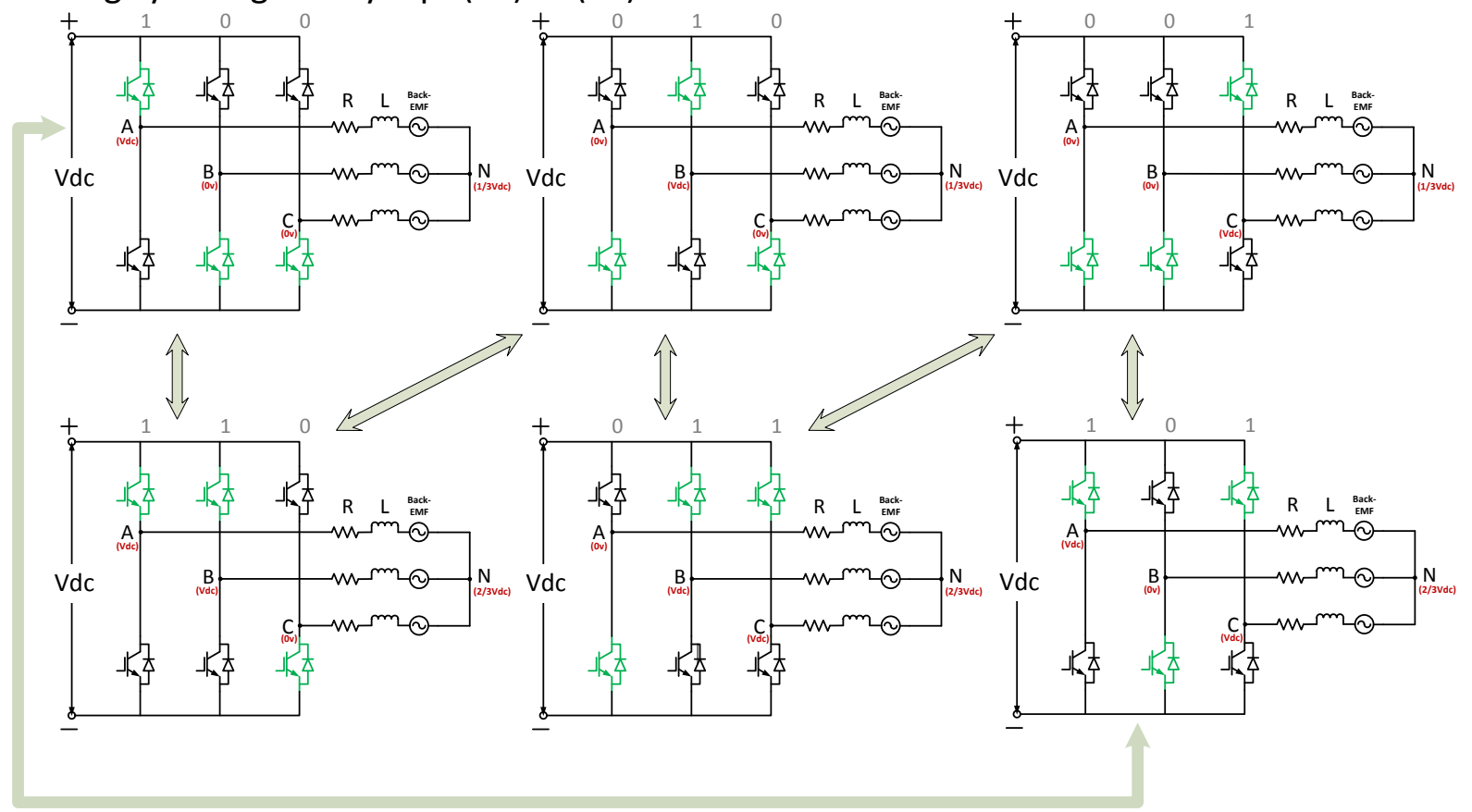

Figure 8. Six switching patterns (electric machine load) 


\begin{tabular}{|c|c|c|}
\hline 100 & $\left\{\begin{array}{c}\Delta i_{A}=\frac{2 V_{d c}-3 E_{m} \cos \left(\omega t_{0}+\varphi\right)-3 R i_{A 0}}{3 L} \Delta t \\
\Delta i_{B}=\frac{-V_{d c}-3 E_{m} \cos \left(\omega t_{0}+\varphi-2 \pi / 3\right)-3 R i_{B 0}}{3 L} \Delta t \\
\Delta i_{C}=\frac{-V_{d c}-3 E_{m} \cos \left(\omega t_{0}+\varphi+2 \pi / 3\right)-3 R i_{C 0}}{3 L} \Delta t\end{array}\right.$ & (32) \\
\hline 110 & $\left\{\begin{array}{c}\Delta i_{A}=\frac{V_{d c}-3 E_{m} \cos \left(\omega t_{0}+\varphi\right)-3 R i_{A 0}}{3 L} \Delta t \\
\Delta i_{B}=\frac{V_{d c}-3 E_{m} \cos \left(\omega t_{0}+\varphi-2 \pi / 3\right)-3 R i_{B 0}}{3 L} \Delta t \\
\Delta i_{C}=\frac{-2 V_{d c}-3 E_{m} \cos \left(\omega t_{0}+\varphi+2 \pi / 3\right)-3 R i_{C 0}}{3 L} \Delta t\end{array}\right.$ & (33) \\
\hline 010 & $\left\{\begin{array}{c}\Delta i_{A}=\frac{-V_{d c}-3 E_{m} \cos \left(\omega t_{0}+\varphi\right)-3 R i_{A 0}}{3 L} \Delta t \\
\Delta i_{B}=\frac{2 V_{d c}-3 E_{m} \cos \left(\omega t_{0}+\varphi-2 \pi / 3\right)-3 R i_{B 0}}{3 L} \Delta t \\
\Delta i_{C}=\frac{-V_{d c}-3 E_{m} \cos \left(\omega t_{0}+\varphi+2 \pi / 3\right)-3 R i_{C 0}}{3 L} \Delta t\end{array}\right.$ & (34) \\
\hline 011 & $\left\{\begin{array}{c}\Delta i_{A}=\frac{-2 V_{d c}-3 E_{m} \cos \left(\omega t_{0}+\varphi\right)-3 R i_{A 0}}{3 L} \Delta t \\
\Delta i_{B}=\frac{V_{d c}-3 E_{m} \cos \left(\omega t_{0}+\varphi-2 \pi / 3\right)-3 R i_{B 0}}{3 L} \Delta t \\
\Delta i_{C}=\frac{V_{d c}-3 E_{m} \cos \left(\omega t_{0}+\varphi+2 \pi / 3\right)-3 R i_{C 0}}{3 L} \Delta t\end{array}\right.$ & (35) \\
\hline 001 & $\left\{\begin{array}{c}\Delta i_{A}=\frac{-V_{d c}-3 E_{m} \cos \left(\omega t_{0}+\varphi\right)-3 R i_{A 0}}{3 L} \Delta t \\
\Delta i_{B}=\frac{-V_{d c}-3 E_{m} \cos \left(\omega t_{0}+\varphi-2 \pi / 3\right)-3 R i_{B 0}}{3 L} \Delta t \\
\Delta i_{C}=\frac{2 V_{d c}-3 E_{m} \cos \left(\omega t_{0}+\varphi+2 \pi / 3\right)-3 R i_{C 0}}{3 L} \Delta t\end{array}\right.$ & (36) \\
\hline 101 & $\left\{\begin{array}{c}\Delta i_{A}=\frac{V_{d c}-3 E_{m} \cos \left(\omega t_{0}+\varphi\right)-3 R i_{A 0}}{3 L} \Delta t \\
\Delta i_{B}=\frac{-2 V_{d c}-3 E_{m} \cos \left(\omega t_{0}+\varphi-2 \pi / 3\right)-3 R i_{B 0}}{3 L} \Delta t \\
\Delta i_{C}=\frac{V_{d c}-3 E_{m} \cos \left(\omega t_{0}+\varphi+2 \pi / 3\right)-3 R i_{C 0}}{3 L} \Delta t\end{array}\right.$ & (37) \\
\hline
\end{tabular}

where $R$ is the electric machine winding resistance, $L$ the inductance, $E_{\mathrm{m}}$ the back EMF, $i_{\mathrm{A} 0}, i_{\mathrm{B} 0}$ and $i_{\mathrm{C} 0}$ are the initial value of the three-phase current at the beginning of one switching cycle.

Figure 9 shows the flow chart of the numerical method of calculating the instantaneous threephase current, inverter input current and capacitor current. Figures 10-12 show the three-phase current, inverter input current and capacitor voltage ripple for three different types of load using the numerical method. 


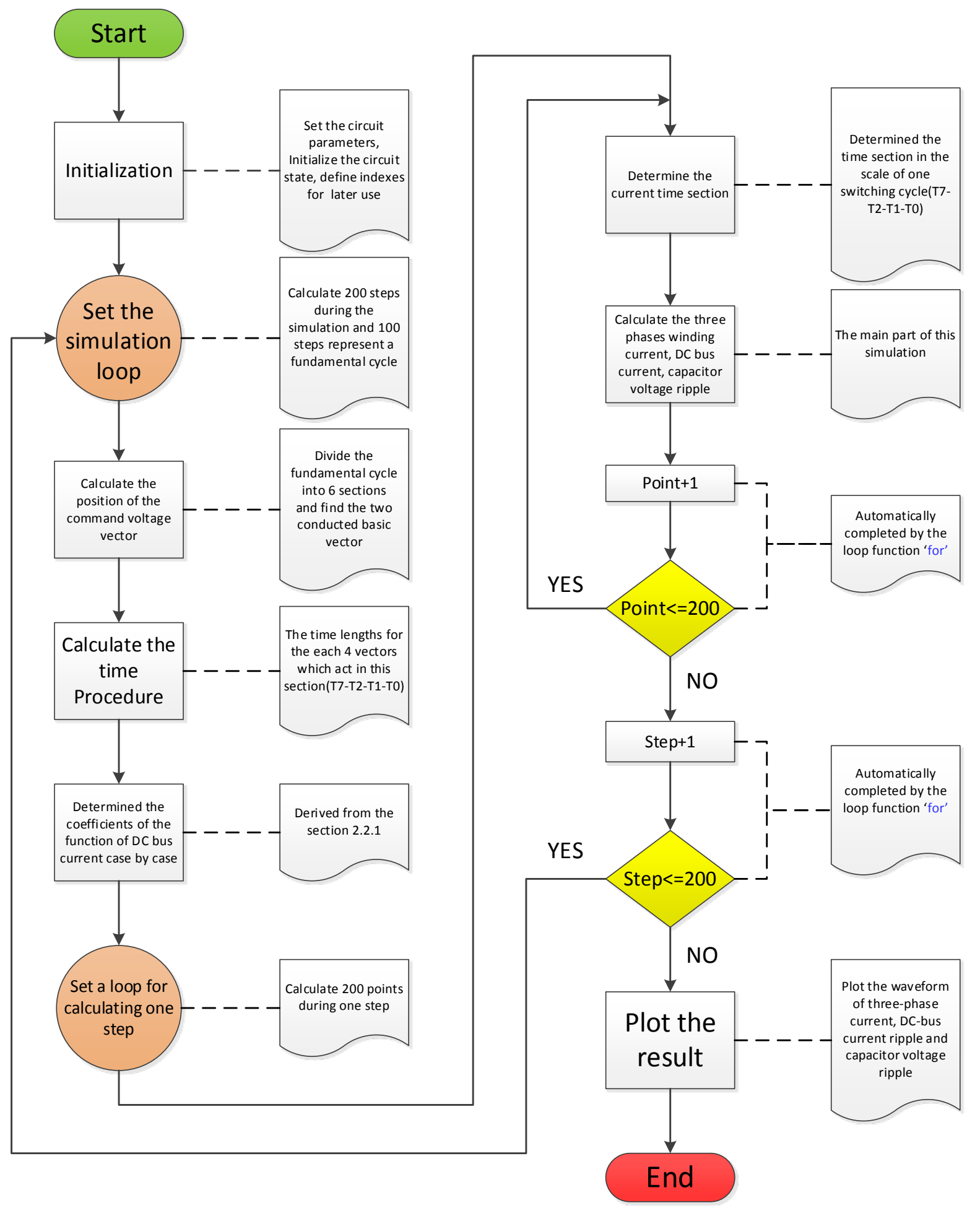

Figure 9. Numerical method of reconstructing instantaneous three-phase current 


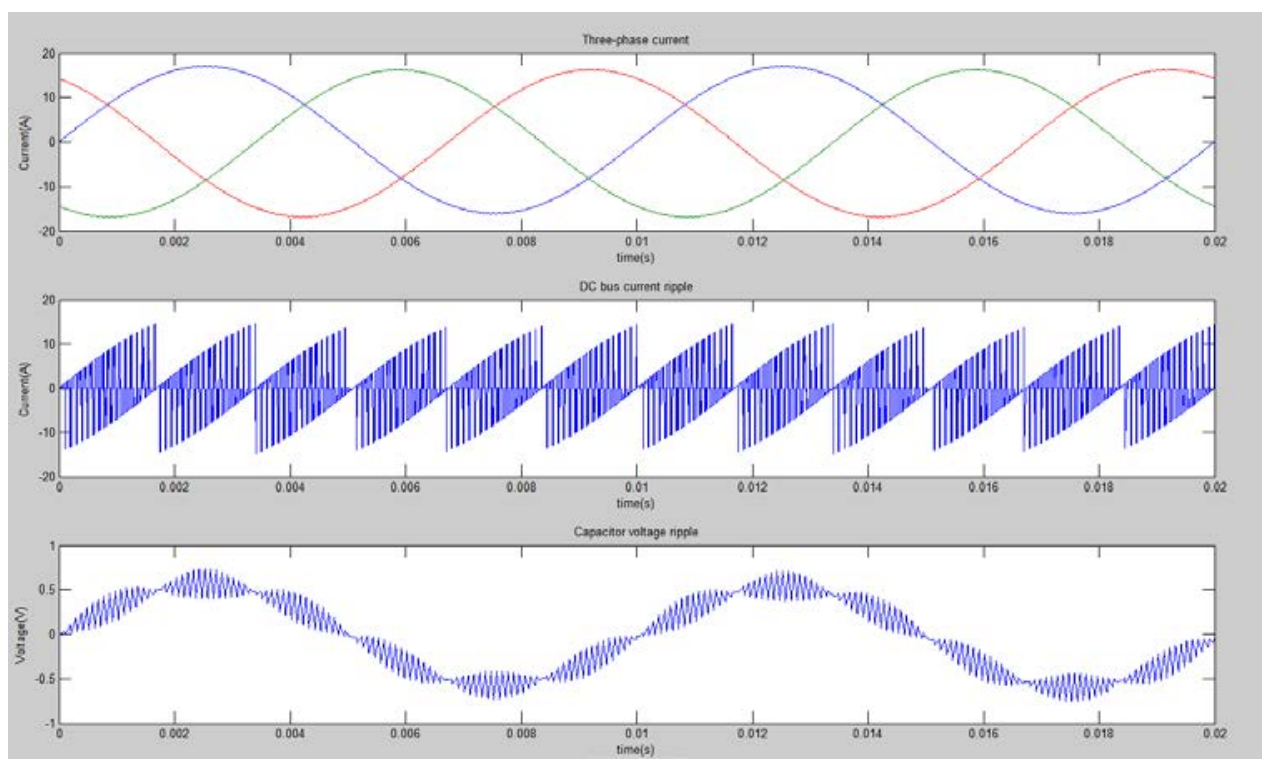

Figure 10. Instantaneous waveforms with L load

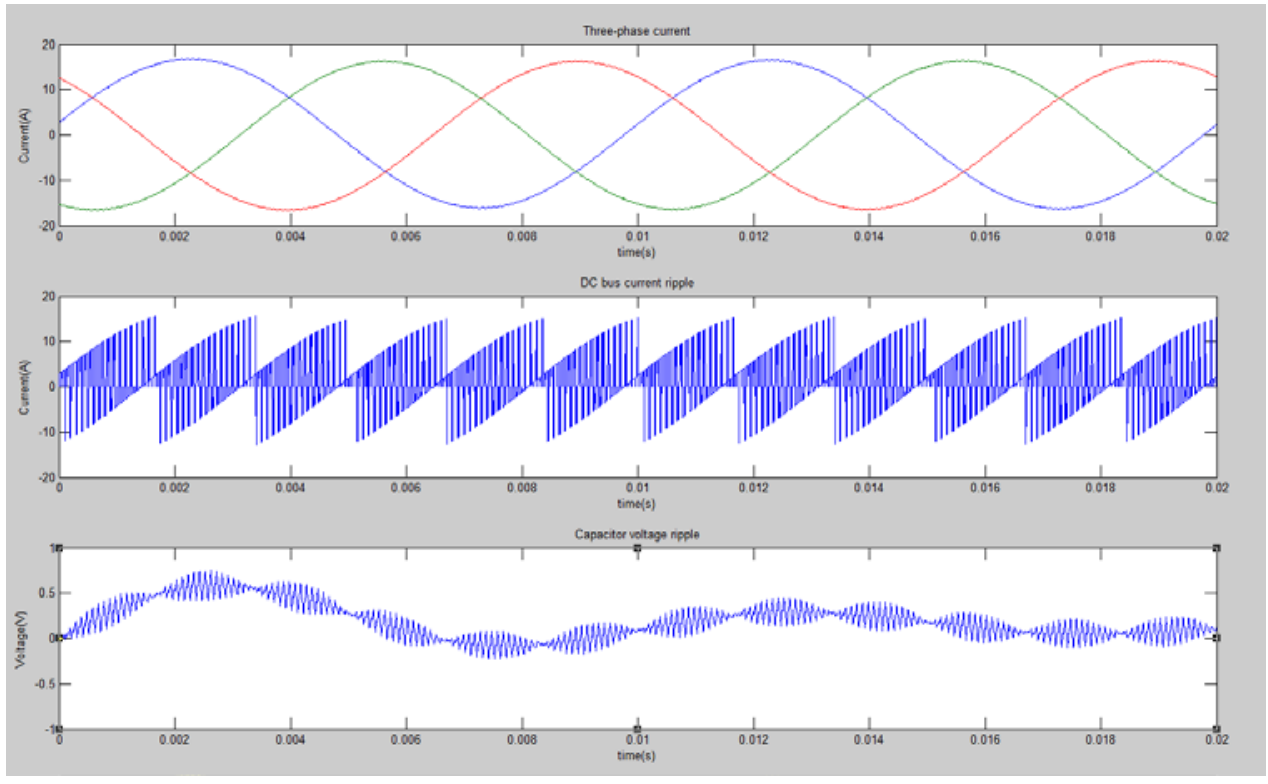

Figure 11. Instantaneous waveforms with RL load 


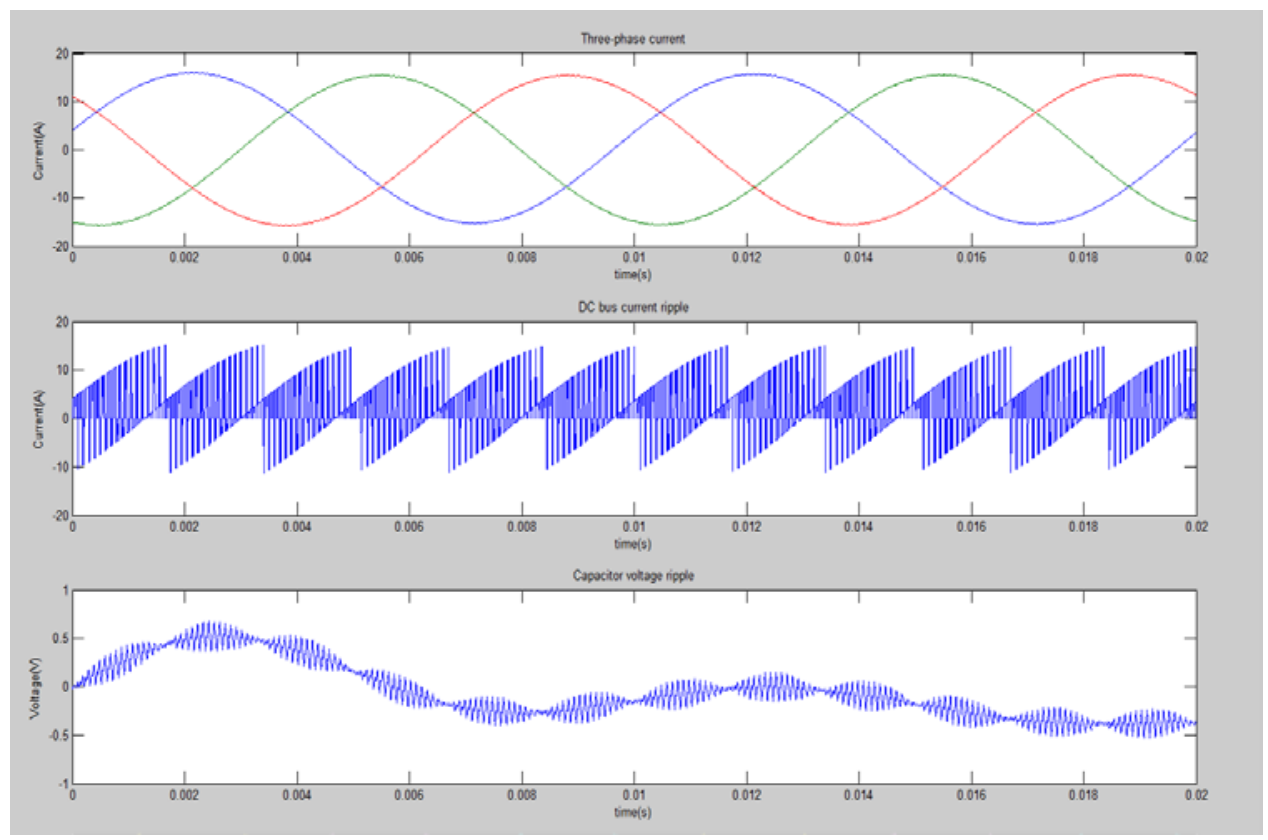

Figure 12. Instantaneous waveforms with electric machine model

\section{Analysis for Non-ideal Voltage Source}

In the previous analysis, we have assumed that the input voltage source is an ideal source without any internal resistance. In the real-world application, the input voltage source always has a small internal resistance. That is also why a large DC link capacitor is needed to provide smooth input voltage to the three-phase inverter. For the following analysis, we will take into account the effect of the voltage source internal resistance. In Figure 13, the input voltage source is represented by an ideal voltage source in series with an internal resistance.

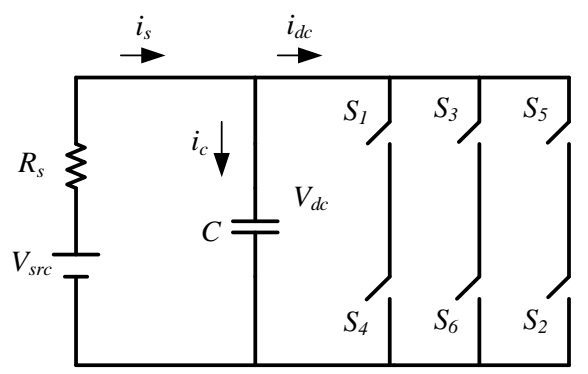

Figure 13. Model of non-ideal input voltage source

For the system shown in Figure 12, Eq. (38) exists:

$$
\left\{\begin{array}{c}
i_{d c}=i_{s}-i_{c} \\
i_{c}=C \frac{d V_{d c}}{d t} \\
V_{d c}=V_{s r c}-R_{s} i_{s}
\end{array}\right.
$$

where $\mathrm{C}$ is the capacitance of the $\mathrm{DC}$ link capacitor, $R_{S}$ is the internal resistance of the input voltage source. In Eq. (25), we assume the input voltage $V_{\mathrm{src}}$, its internal resistance $R_{\mathrm{s}}$ and the 
capacitance $C$ are known. In addition, the inverter input current $i_{\mathrm{dc}}$ can be calculated by Eq. (39), regarded as a known variable.

$$
i_{d c}=i_{A} S_{A}+i_{B} S_{B}+i_{C} S_{C}
$$

where $i_{A}, i_{B}$ and $i_{C}$ are the three-phase current, $S_{A}, S_{B}$ and $S_{C}$ are the three-phase switching function. The three-phase current may be obtained using the numerical method presented in the previous part. Therefore, the capacitor current and the voltage source current may be written as:

$$
\begin{aligned}
& \frac{d i_{c}}{d t}+\frac{i_{c}}{R_{s} C}+\frac{d i_{d c}}{d t}=0 \\
& i_{s}=i_{C}+i_{d c}
\end{aligned}
$$

Eqs. (39) and (40) are later used to calculate the instantaneous capacitor current and the source current in Matlab. Figure 14 shows the results of the voltage source current, capacitor voltage and current using the numerical method. Figure 15 shows the flow chart of the Matlab script.

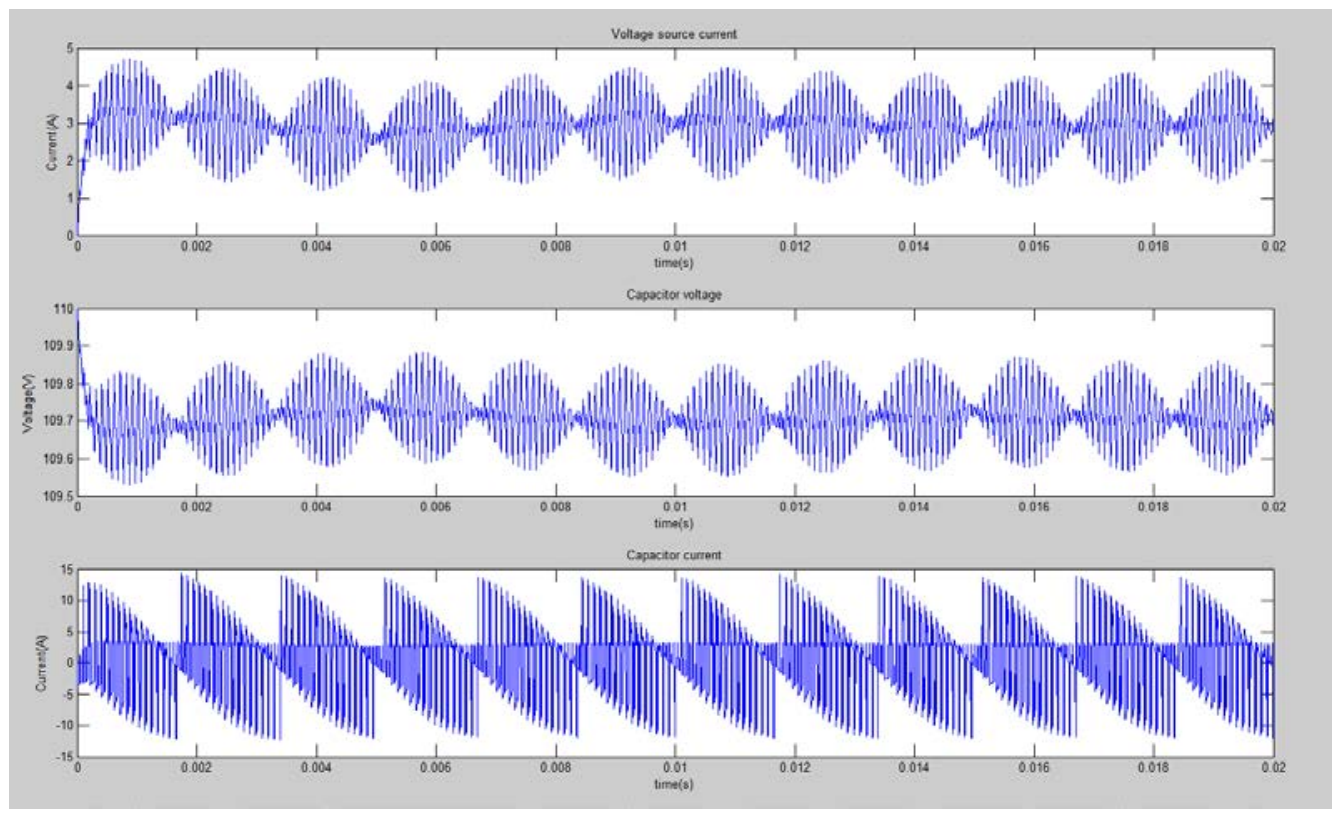

Figure 14. Voltage source ripple and capacitor current ripple using numerical method 


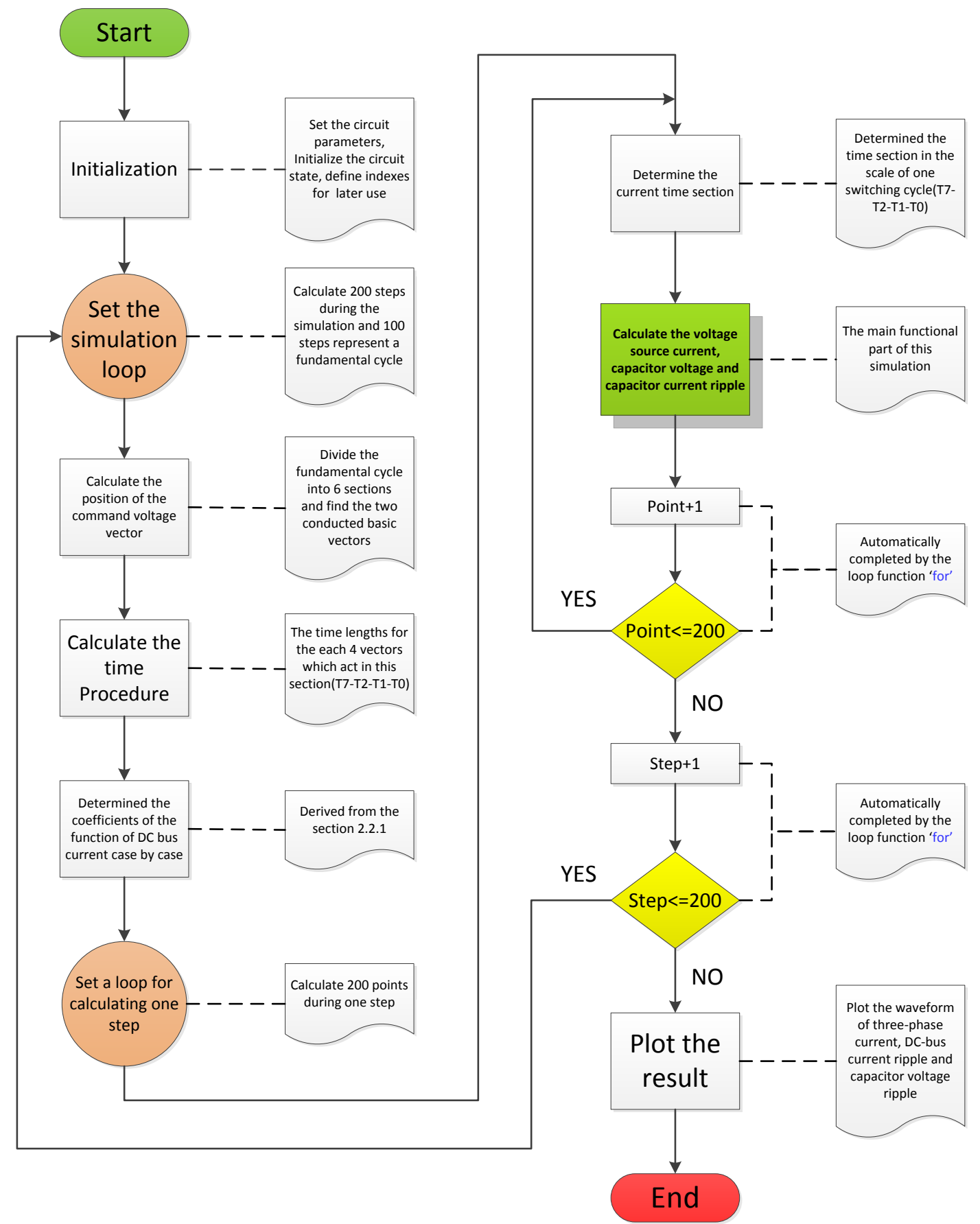

Figure 15. Flow chart of calculating capacitor current and voltage source current for non-ideal voltage source

\section{Summary}

This report first reviews the challenges that the bulky DC link capacitor of the electric vehicle traction inverter presents to further power density increase and cost reduction. Then this work presents the numerical method of calculating the DC link capacitor current ripple of the traction converter for electric vehicle applications. The effect of internal resistance of the input voltage source is taken into account for the math modeling. 


\section{References}

[1] J. Kolar and S. Round, "Analytical calculation of the RMS current stress on the DC-link capacitor of voltage-PWM converter systems," IEE Proceedings of Electric Power Applications, Vol. 153, No. 4, July 2006.

[2] F. Kieferndorf, M. Förster and T. Lipo, "Reduction of DC-Bus Capacitor Ripple Current with PAM/PWM Converter," IEEE Transactions on Industry Applications, Vol. 40, No. 2, March/April 2004.

[3] J. Zhu and A. Pratt, "Capacitor Ripple Current in an Interleaved PFC Converter," IEEE Transaction on Power Electronics, Vol. 24, No. 6, June 2009.

[4] T.-P Chen, "Common-Mode Ripple Current Estimator for Parallel Three-Phase Inverters," IEEE Transaction on Power Electronics, Vol. 24, No. 5, May 2009.

[5] K. Ramachandrasekhar and S. Srinivas, "Discontinuous Decoupled PWMs for Reduced Current Ripple in a Dual Two-Level Inverter Fed Open-End Winding Induction Motor Drive," IEEE Transaction on Power Electronics, Vol. 28, No. 5, May 2013.

[6] H. van der Broeck, H. C. Skudelny and G. Stanke, "Analysis and Realization of a Pulsewidth Modulator Based on Voltage Space Vectors," IEEE Transactions on Industry Applications, Vol. 24, No. 1, January/February 1988.

[7] J. Kolar, H. Ertl and F. Zach, "Calculation of the Passive and Active Component Stress Of Three Phase PWM Converter Systems with High Pulse Rate," 3rd European Conference on Power Electronics and Applications, pp. 1303-1311, October 1989.

[8] G. Su and L. Tang, "A segmented traction drive system with a small dc bus capacitor," Energy Conversion Congress and Exposition, pp. 2847-2853, September 2012

[9] A. Hava, R. Kerkman and T. Lipo, "Simple Analytical and Graphical Methods for CarrierBased PWM-VSI Drives," IEEE Transaction on Power Electronics, Vol. 14, No. 1, January 1999

[10] S. Kim, Y. Yoon and S. Sul, "Pulsewidth Modulation Method of Matrix Converter for Reducing Output Current Ripple," IEEE Transaction on Power Electronics, Vol. 25, No. 10, October 2010

[11] B. Vafakhah, J. Salmon and A. Knight, "A New Space-Vector PWM With Optimal Switching Selection for Multilevel Coupled Inductor Inverters," IEEE Transaction on Industrial Electronics, Vol. 57, No. 7, July 2010

[12] M. Gasperi, "Life Prediction Modeling of Bus Capacitors in AC Variable-Frequency Drives," IEEE Transactions on Industry Applications, Vol. 41, No. 6, November/December 2005. 



\section{GOTREC \\ AND EDUCATION CONSORTIUM}

P.O. Box 751

Portland, OR 97207

OTREC is dedicated to stimulating and conducting collaborative multi-disciplinary research on multi-modal surface transportation issues, educating a diverse array of current practitioners and future leaders in the transportation field, and encouraging implementation of relevant research results. 